\title{
CHCHD7 wt Allele
}

National Cancer Institute

\section{Source}

National Cancer Institute. CHCHD7 wt Allele. NCI Thesaurus. Code C97404.

Human CHCHD7 wild-type allele is located in the vicinity of $8 q 12.1$ and is approximately 7 $\mathrm{kb}$ in length. This allele, which encodes coiled-coil-helix-coiled-coil-helix domain-containing protein 7, may play a role in the determination of stature. A chromosomal inversion inv(8) (q12.1;q12.1) of this gene and the PLAG1 gene is associated with salivary gland pleiomorphic adenoma. 